\title{
IMPLEMENTASI MANAJEMEN PENDIDIKAN BERBASIS KARAKTER
}

\author{
Colle Said \\ Unismuh Palu
}

Abstract

Character-based education management aims to integrate everything, both personal, spiritual, attitudes and behaviors as well as material related to the achievement of educational goals. In the process, education of all the efforts of the people involved in the process of achieving these educational goals is then effectively integrated, organized and coordinated, and all materials needed, and existing ones are used efficiently. Character-based education management in schools can be as a basic knowledge that has its own characteristics that are different from other administrative sciences that lie in its operational principles, and not in general principles. Every activity in the education administration process is directed to achieve educational goals. In the management of character-based education, it is also necessary to have good coordination and supervision or supervision from the leadership.

Keywords: Character based education management

Abstrak

Manajemen pendidikan berbasis karakter bertujuan untuk mengintegrasian segala sesuatu, baik personal, spiritual, sikap dan prilaku maupun material yang bersangkut paut dengan pencapaian tujuan pendidikan. Dalam proses tersebut, pendidikan segenap usaha orang-orang yang terlibat di dalam proses pencapaian tujuan pendidikan tersebut, lalu diintegrasikan, diorganisasiikan, dan dikoordinasii secara efektif, dan semua materi yang diperlukan, dan yang telah ada dimanfaatkan secara efesien. Manajemen pendidikan berbasis karakter di sekolah dapat sebagai sebuah dasar ilmu yang mempunyai karakteristik tersendiri yang berbeda dengan ilmu administrasi lainnya yang terletak pada prinsip-prinsip operasionalnya, dan bukan pada prinsip-prinsip umumnya. Setiap kegiatan di dalam proses administrasi pendidikan di arahkan untuk mencapai tujuan pendidikan. dalam menejemen pendidikan berbasis karakter ini diperluakan pula adanya koordinasi dan pengawasan atau supervisi yang baik dari pimpinan.

Kata Kunci: Pendidikan karakter, manajemen pendidikan 


\section{Pendahuluan}

Pendidikan karakter dipahami sebagai upaya penanaman kecerdasan dalam berpikir, penghayatan dalam bentuk sikap, dan pengamalan dalam bentuk perilaku yang sesuai dengan nilai-nilai luhur yang menjadi jati dirinya, diwujudkan dalam interaksi dengan Tuhannya, diri sendiri, antar sesama, dan lingkungannya. Pendidikan karakter juga diartikan sebagai the deliberate us of all dilemensions of school life to foster optimal character development (usaha kita secara sengaja dari seluruh dimensi kehidupan sekolah untuk membantu pengembangan karakter dengan optimal) ${ }^{1}$. Hal ini berarti bahwa untuk mendukung $^{2}$ perkembangan karakter peserta didik harus melibatkan seluruh komponen di sekolah baik aspek isi kurikulum (the content of the curriculum), proses pembelajaran (the procces of instruction), kualitas hubungan (the quality of relationships), penanganan mata pelajaran (the handling of discipline), pelaksanaan aktivitas ko-kurikuler, serta etos seluruh lingkungan sekolah.

Melalui pendidikan karakter sekolah harus berpotensi untuk membawa peserta didik memiliki nilai-nilai karakter mulia seperti hormat dan peduli pada orang lain, tanggung jawab, memiliki integritas, dan disiplin. Selain itu, pendidikan karakter juga harus mampu menjauhkan peserta didik dari sikap dan perilaku yang tercela. Pendidikan karakter tidak hanya berkaitan dengan benar salah, akan tetapi bagaimana menanamkan tentang kebiasaan tentang hal-hal yang baik dalam kehidupan sehingga peserta didik memiliki kesadaran dan pemahaman yang tinggi serta kepedulian dan komitmen untuk menetapkn kebajikan dalam kehidupan seharihari. Sedangkan manajemen Pendidikan adalah suatu kegiatan atau rangkaian kegiatan yang berupa proses pengelolaan usaha kerjasama sekelompok manusia yang tergabung dalam organisasi pendidikan, untuk mencapai tujuan pendidikan yang telah ditetapkan sebelumnya, agar efektif dan efisien. Arti manajemen pendidikan yaitu adanya usaha bersama untuk mencapai tujuan

1 Malik Fadjar, Holistik Pemikiran Pendidikan, (Jakarta: PT. Raja Grafindo Persada, 2005), h. 68.

2 Ibid h 69 
yang telah ditetapkan, maka usaha tersebut terjadi pada satu organisasi. Manajemen pendidikan dapat didefinisikan sebagai seni dan ilmu mengelola sumber daya pendidikan untuk mewujudkan suasana belajar dan proses pembelajaran agar peserta didik secara aktif mengembangkan potensi dirinya untuk memiliki kekuatan spiritual keagamaan, pengendalian diri, kepribadian, kecerdasan, akhlak mulia, serta keterampilan yang diperlukan dirinya, masyarakat, bangsa dan negara. Buku ini cocok dipakai sebagai referensi bagi para mahasiswa keguruan, guru, dosen dan pengelola di bidang pendidikan.

Manajemen kemudian diartikan sebagai suatu rentetan atau langkah yang terpadu untuk mengembangkan suatu organisasi sebagai suatu system yang bersifat sosial, ekonomi, dan tekhnis, dimana hal tersebut merupakan suatu kesatuan dinamis yang terdiri dari bagian-bagian yang berhubungan secara organik. Dinamis memiliki arti yaitu bergerak atau berkembang ke satu tujuan. Sosial berarti bergerak di dalam dan yang menggerakkan sistem itu adalah manusia. sedangkan ekonomi berarti kegiatan dalam sistem bertujuan untuk memenuhi kebutuhan manusia. dan teknis berarti dalam kegiatan dipakai harta, alat-alat dan cara-cara tertentu. ${ }^{3}$

Sekolah dapat berjalan karena adanya konsep manajemen yang terstruktur. Manajemen dalam organisasi sekolah sering disebut dengan manajemen pendidikan. Manajemen pendidikan diartikan pula Administrasi pendidikan. Administrasi pendidikan ialah segenap proses penyerahan dan pengintegrasian segala sesuatu, baik personal, spiritual, maupun material yang bersangkut paut dengan pencapaian tujuan pendidikan. ${ }^{4}$ Di dalam proses administrasi pendidikan segenap usaha orang-orang yang terlibat di dalam proses pencapaian tujuan pendidikan itu diintegrasikan, diorganisasiikan, dan dikoordinasii secara efektif, dan semua materi yang diperlukan, dan yang telah ada dimanfaatkan secara efesien.

3 Kadarman. Pengantar Ilmu Manajemen. (Jakarta: Gramedia. 1991), 87.

4 Purwanto, M. N. Administrasi dan Supervisi Pendidikan. (Bandung: Remaja Rosdakarya, 2008), 10. 
Konsep manajemen berbasis pendidikan karakter di sekolah merupakan faktor yang penting dalam menyelenggarakan pendidikan dan pengajaran di sekolah yang keberhasilannya diukur oleh prestasi yang didapat, oleh karena itu dalam menjalankan kepemimpinan, harus menggunakan suatu sistem, artinya dalam penyelenggaraan pendidikan di sekolah yang di dalamnya terdapat komponen-komponen terkait yang harus berfungsi optimal yang dipengaruhi oleh kebijakan dan kinerja pimpinan.

Secara konsep, manajemen pendidikan berbasis pendidikan karakter dapat digambarkan sebagai keseluruhan proses kerjasama dengan memanfaatkan semua sumber personil dan materil yang tersedia dan sesuai untuk mencapai tujuan pendidikan yang telah ditetapkan secara efektif dan efisien. Sementara itu, konsep manajemen pendidikan di sekolah sebagai rangkaian kegiatan atau keseluruhan proses pengendalian usaha kerjasama sejumlah orang untuk mencapai tujuan pendidikan secara sistematis yang diselenggarakan dalam sebuah lembaga.

Tantangan lembaga pendidikan adalah mengejar ketertinggalan artinya kompetisi dalam meraih prestasi terlebih dalam menghadapi persaingan global. Dalam konsep manajemen pendidikan, kadang masih ditemukan adanya kontroversi dan inkonsistensi dalam penggunaan istilah manajemen. Ada yang tetap cenderung menggunakan istilah manajemen sehingga dikenal dengan istilah manajemen pendidikan, dan tidak sedikit pula yang menggunakan istilah administrasi sehingga dikenal istilah adminitrasi pendidikan. Dalam studi ini, penulis cenderung untuk mengidentikkan keduanya, sehingga kedua istilah ini dapat digunakan dengan makna yang sama.

Pendidikan merupakan upaya normatif untuk membantu orang lain berkembang ke tingkat normatif lebih baik. ${ }^{5}$ Menurut Qodri Azizy pendidikan adalah suatu usaha sadar untuk

\footnotetext{
5 Ali Asraf, Pendidikan Baru Islam, (Jakarta: Pustaka Firdaus,
} 1993), 2 
mengembangkan kepribadian peserta didik. ${ }^{6}$ Sedangkan karakter dalam Kamus Ilmiah Populer, berarti watak, tabiat, pembawaan atau kebiasaan. ${ }^{7}$ Karakter merupakan cara berpikir dan berperilaku yang menjadi ciri khas tiap individu untuk hidup dan bekerjasama, baik dalam lingkup keluarga, masyarakat, bangsa dan negara. Indivudu yang berkarakter baik adalah indivudu yang bisa membuat keputusan dan siap mempertanggungjawabkan tiap akibat dari keputusan yang dibuat. ${ }^{8}$ Karakter dapat juga dipahami sebagai sifat pribadi yang relatif stabil pada diri individu yang menjadi landasan bagi penampilan perilaku dalam standar nilai dan norma. Karakter menurut Alwisol diartikan sebagai gambaran tingkah laku yang menonjolkan nilai benar-salah, baik-buruk, baik secara eksplisit maupun implisit. ${ }^{9}$

Karakter sebagai nilai kebaikan terpatri dalam diri dan terjewantahkan dalam perilaku. Imam Ghazali menganggap bahwa karakter lebih dekat dengan akhlak, yaitu spontanitas manusia dalam bersikap atau berbuat yang telah menyatu dalam diri manusia sehingga ketika muncul secara tiba-tiba tidak perlu dipikirkan lagi. Jadi individu yang berkarakter baik adalah individu yang dapat membuat keputusan dan siap mempertanggungjawabkan tiap akibat dari keputusan yang dibuatnya. Beberapa tokoh memiliki persepsi tentang karakter, diantaranya: Menurut Simon Philips dalam buku Masnur memberikan pengertian bahwa karakter adalah kumpulan tata nilai yang menuju pada suatu sistem, yang melandasi suatu pemikiran, sikap, dan perilaku yang ditampilkan. ${ }^{10}$ Sedangkan menurut Koesuma menyatakan bahwa karakter sama dengan kepribadian, dimana kepribadian dianggap sebagai ciri atau

\footnotetext{
6 Ahmad Maulanah dkk, Kamus Ilmiah Populer, (Cet. II.Yogyakarta: Absolut, 2004), 202.

7 Sri Nirwanti, Pendidikan Karakter Pengintergrasian 18 Nilai Pembentuk Karakter dalam Mata Pelajaran, (Yogyakarta: Familia, 2011), h. 1. 23. 700

${ }^{8}$ Tim Penyusun Kamus Pusat Bahasa ”Kamus Bahasa Indonesia”, h.

${ }^{9}$ Alwisol, Psikologi Kepribadian (Malang: UMM, 2006), h. 8

${ }^{10}$ Masnur Muhlis, Pendidikan Karakter Menjawab Tantangan Krisis Multidimensional, (Jakarta: Bumi Aksara, 2011), h. 70. 24
} 
karakteristik atau gaya atau sifat khas dari seseorang yang bersumber dari bentukan-bentukan yang diterima dari lingkungan, misalnya, keluarga, masyarakat, atau bisa pula merupakan bawaan yang dibawa sejak lahir. ${ }^{11}$

Leonardo A. Sjiamsuri dalam bukunya Kharisma Versus Karakter yang dikutip Damanik mengemukakan bahwa karakter merupakan siapa anda sesunggunya. ${ }^{12}$ Batasan ini menunjukkan bahwa karakter sebagai identitas yang dimiliki seseorang yang bersifat menetap sehingga seseorang atau sesuatu itu berbeda dari yang lain pendidikan karakter menurut T. Ramli mengemukakan bahwa pendidikan karakter memiliki esensi dan makna yang sama dengan pendidikan moral dan pendidikan akhlak. Tujuannya adalah untuk membentuk pribadi peserta didik menjadi manusia yang baik, masyarakat dan warga Negara yang baik. ${ }^{13}$ Dari penjelasan di atas dapat disimpulkan bahwa pendidikan karakter adalah segala sesuatu yang dilakukan guru, yang mampu mempengaruhi karakter peserta didik. Guru membantu membentuk watak peserta didik. Hal ini mencakup keteladanan perilaku guru, cara guru berbicara atau menyampaikan materi, cara guru bertoleransi, dan berbagai hal terkait lainnya.

Dan pendidikan karakter merupakan keseluruhan dinamika relasional antar pribadi dengan berbagai macam dimensi, baik dari dalam maupun dari luar dirinya. Agar pribadi itu semakin dapat menghayati kebebasannya sehingga dapat semakin bertanggung jawab atas pertumbuhan dirinya sendiri sebagai pribadi dan perkembangan orang lain dalam hidup mereka. Sedangkan manajemen dan kepemimpinan sebenarnya memiliki kajian yang berbeda. Tetapi keduanya memiliki hubungan yang dekat. Memimpin terkait dengan menggerakkan dan mengarahkan kegiatan orang, sedangkan yang terkait dengan kegiatan mengatur orang, yang bisa dimaknai secara

${ }^{11}$ Doni Koesuma A, Pendidikan Karakter; Strategi Mendidik Anak di Zaman Global, (Jakarta: Grafindo:2010), h. 80

12 Anita Yus, Pengembangan Karakter Melalui Hubungan AnakKakek-Nenek, dalam Arismantoro (Peny.), Tinjauan Berbagai Aspek Charakter Building (Tiara Wacana: Yogyakarta, 2008), h. 91

13 http://www.Seputarpengetahuan.com/2016/03/6-pendidikankarakter-menurut-para-ahli. html. 25 
luas misalnya menempatkan, memberi tugas, membagi-bagi, mencarikan jalan keluar, memperlancar dan mengubah-ubah tugas yang diberikan. Mengelola pendidikan bukanlah hal hal yang mudah untuk dilakukan karena mengelola pendidikan sangat rumit.

Manajemen secara umum adalah sebuah proses perencanaan, pengorganisasian, pengarahan, dan pengawasan usaha-usaha para anggota organisasi dan penggunaan sumber daya-sumber daya organisasi lainnya agar mencapai tujuan organisasi yang telah ditetapkan. Sedangkan dalam konteks sekolah yaitu Manajemen sekolah menurut buku manajamen sekolah sebenarnya merupakan aplikasi ilmu manajemen dalam bidang persekolahan. Ketika istilah manajemen diterapkan dalam bidang pemerintahan akan menjadi manajemen pemerintahan, dalam bidang pendidikan menjadi manajemen pendidikan, begitu seterusnya.

Manajemen sekolah adalah proses pendayagunaan sumber-sumber manusiawi bagi penyelenggara sekolah secara efektif. Sedangkan dalam konteks pendidikan ada juga manajemen pendidikan. Manajemen pendidikan adalah proses penataan kelembagaan pendidikan, dengan melibatkan sumber potensial baik yang bersifat manusia maupun yang bersifat non manusia guna mencapai tujuan pendidikan secara efektif dan efisien..

Di sekolah, diperlukan adanya manajemen yang efektif agar pekerjaan dapat berjalan lancar. Mengingat beratnya proses pengelolaan pendidikan di sekolah, maka kepala sekolah sebagai pemimpin harus memahami seni memimpin. Dalam kata lain kepala sekolah harus menjadi manajer-leader di sekolah yang mengerti serta menerapakan manajemen kepemimpinan.

\section{Pembahasan}

Berbicara tentang kegiatan pendidikan, di bawah ini beberapa pandangan dari para ahli tentang bidang-bidang kegiatan yang menjadi wilayah garapan manajemen pendidikan berbasis karakter. mengelompokkannya ke dalam tiga bidang garapan yaitu : Administrasi material berbasis karakter, yaitu kegiatan yang menyangkut bidang-bidang materi/ benda-benda, seperti ketatausahaan sekolah, administrasi keuangan, gedung 
dan alat-alat perlengkapan sekolah dan lain-lain. Administrasi personal berbasis karakter, mencakup di dalamnya administrasi personal guru dan pegawai sekolah, juga administrasi murid. Administrasi kurikulum berbasis karakter, seperti tugas mengajar guru-guru, penyusunan silabus atau rencana pengajaran tahunan, persiapan harian dan mingguan dan sebagainya.

Pendidikan karakter adalah upaya-upaya terencana dan terperinci yang dilaksanakan secara sistematis dan berkesinambungan untuk membantu peserta didik dalam mengimplementasikan nilai-nilai kebaikan yang berhubungan dengan manusia dengan Tuhan, diri sendiri, sesama manusia lainnya, lingkungan, Bangsa dan Negara yang diwujudkan dalam pikiran, perasaan, sikap, perkataan dan perbuatan. Pendidikan karakter juga dihubungkan dengan sikap rencana sekolah, yang dirancang bersama lembaga masyarakat yang lain, untuk membentuk secara langsung perilaku peserta didik. ${ }^{14}$ Dengan demikian, idealnya pelaksanaan pendidikan karakter merupakan bagian yang terintegrasi dengan manajemen pendidikan di sekolah. Pendidikan karakter merupakan aspek yang penting untuk kesuksesan manusia di masa depan. Karakter yang kuat akan membentuk mental yang kuat. Sedangkan mental yang kuatakan melahirkan spirit yang kuat, pantang menyerah, berani mengalami proses panjang, serta menerjang arus badai perubahan.

Karakter yang kuat merupakan prasyarat untuk menjadi seorang pemenang dalam medan kompetisi kuat seperti saat ini dan yang akan datang, yang dikenal dengan era kompetitif. Bagi seorang yang berkarakter lemah, tidak akan ada peluang untuk menjadi pemenang, akan tetapi hanya menjadi pecundang, teralienasi, dan termarginalkan di lingkungan masyarakat. Oleh karena itu pendidikan karakter menjadi keniscayaan bagi bangsa ini untuk membangun mental pemenang bagi generasi bangsa dimasa yang akan datang. Mengingat fakta mengenai pendidikan sekolah selama ini yang dikatakan gagal pada aspek pembentukan karakter. Sekolah terlalu terpesona dengan

14 Zubaiedi, Desain Pendidikan Karakter; Konsepsi dan Aplikakasinya Dalam Lembaga Pendidikan.h. 15 
targettarget akademis dan melupakan pendidikan karakter. Realitas ini membuat kreatifitas, keberanian menghadapi resiko, kemandirian, dan ketahanan melalui berbagai ujian hidup menjadi lemah. Akibatnya anak menjadi frustasi, mudah menyerah, dan kehilangan semangat juang sampai titik darah penghabisan.

Peneliti mendefenisikan kepemimpinan menurut pandangan Stogdil, bahwa : There are almost as many definitions of leadership as there are persons who have attempted to define the concept ${ }^{15}$ Kepemimpinan diterjemahkan ke dalam istilah sifat-sifat, perilaku pribadi, pengaruh terhadap orang lain, pola-pola interaksi, hubungan kerja sama antarperan, kedudukan dari satu jabatan administratif, dan persepsi dari lainlain tentang legitimasi pengaruh. ${ }^{16}$

Kepemimpinan pendidikan adalah suatu kemampuan dan proses mempengaruhi, membimbing, mengkoordinir, dan menggerakkan orang lain yang ada hubungannya dengan pengembangan ilmu pendidikan dan pelaksanaan pendidikan dan pengajaran, agar kegiatan-kegiatan yang dijalankan dapat lebih efisien dan efektif di dalam pencapaian tujuan-tujuan pendidikan dan pengajaran.

1. Manajemen Sekolah

Setiap unsur organisasi baik sekolah maupun organisasi nonnsekolah pasti memiliki sistem manajemen. Manajemen adalah proses untuk mencapai tujuan-tujuan organisasi dengan melakukan kegiatan dari empat fungsi utama yaitu merencanakan (planning), mengorganisasi (organizing), memimpin (leading), dan mengendalikan (controlling). Dengan demikian, manajemen adalah sebuah kegiatan yang berkesinambungan. Sebagai seorang manajer, kepala sekolah harus mengatur sekolahnya sesuai dengan prinsip-prinsip umum manajemen. Menurut Henry Fayol, prinsip tersebut terdiri dari : Pembagian kerja/tugas,

15 Wahjosumidjo. (2008). Kepemimpinan Kepala Sekolah Tinjauan Teoritik dan Permasalahannya. Jakarta: Rajawali Press.

16 Yukl, G. A. (1981). Leadership In Organizations. Englewood: Prentice-Hall Inc 
Wewenang dan tanggung jawab, Aturan dan Disiplin, Kesatuan perintah dan pengarahan dan Penggajian.

Selain lima hal diatas sebagai manajer kepala sekolah juga harus memahami serta melaksanakan definisi manajemen, sebagaimana dijelaskan oleh Ricky W. Griffin, manajemen adalah sebuah proses perencanaan, pengorganisasian, pengkoordinasian, dan pengontrolan sumber daya untuk mencapai sasaran (goals) secara efektif dan efesien.

2. Manajemen Kurikulum dan Pembelajaran

Manajemen kurikulum merupakan subtansi manajemen yang utama di sekolah. Prinsip dasar manajemen kurikulum ini adalah berusaha agar proses pembelajaran dapat berjalan dengan baik, dengan tolok ukur pencapaian tujuan oleh siswa dan mendorong guru untuk menyusun dan terus menerus menyempurnakan strategi pembelajarannya. Tahapan manajemen kurikulum di sekolah dilakukan melalui empat tahap Perencanaan, Pengorganisasian dan koordinasi, Pelaksanaan, Pengendalian.

Dalam konteks Kurikulum Tingkat Satuan Pendidikan dikemukakan tentang siklus manajemen kurikulum yang terdiri dari empat tahap : tahap perencanaan, tahap pengembangan, tahap implementasi atau pelaksanaan dan tahap penilaian.

3. Manajemen Kepegawaian

Pegawai pada masa kini memfasilitasi aktualisasi dan pengembangan kompetensi para pegawai melalui programprogram pengembangan dan pemberdayaan yang dilakukan secara sistematik. Pengembangan dan pemberdayaan pegawai merupakan bagian dari MSDM (manajemen sumber daya manusia) yang memiliki fungsi untuk memperbaiki kompetensi, adaptabilitas dan komitmen para pegawai. Dengan cara demikian organisasi memiliki kekuatan bukan saja sekedar bertahan (survival), melainkan tumbuh (growth), produktif (productive), dan kompetitif (competitive). Dan dalam proses demikian, dukungan pegawai yang kuat melahirkan organisasi yang memiliki adaptabilitas dan kapasitas memperbaharui dirinya (adaptability and self-renewal capacity). Ada lima aspek 
kajian manajemen kepegawaian, yaitu : Perencanaan kebutuhan, Rekrutmen dan seleksi, Pembinaan dan pengembangan, Mutasi dan promosi, dan Kesejahteraan. Demikian pula kebijakan kompensasi penggajian dan kesejahteraan dalam penilaian kinerja yang dilakukan dengan adil dan tepat dapat melahirkan motivasi berprestasi pada para pegawai. Fungsi-fungsi manajemen kepegawaian seperti itu masih belum cukup, apabila tidak disertai dengan kebijakan pengembangan dan pemberdayaan pegawai yang dilakukan secara sistematik.

4. Manajemen Kepala Sekolah

Manajemen pendidikan di sekolah adalah merencanakan sesuatu atau mencari strategi yang terbaik, mengorganisasi dan mengkoordinasi sumber-sumber pendidikan yang masih berserakan agar menyatu dalam melaksanakan pendidikan, dan mengadakan kontrol terhadap pelaksanaan dan hasil pendidikan. Keefektifan manajemen pendidikan ditentukan oleh profesionalisme manajer pendidikan. Adapun sebagai manajer terdepan kepala sekolah merupakan figur kunci dalam mendorong perkembangan dan kemajuan sekolah. Kepala sekolah tidak hanya meningkatkan tanggung jawab dan otoritasnya dalam program-program sekolah, kurikulum dan keputusan personil, tetapi juga memiliki tanggung jawab untuk meningkatkan akuntabilitas keberhasilan siswa dan programnya. Kepala sekolah harus pandai memimpin kelompok dan mampu melakukan pendelegasian tugas dan wewenang.

Oleh karena itu kepala sekolah hendaknya harus memiliki sikap-sikap yang mencerminkan : Manajer Sekolah, Pemimpin Sekolah, Administrator Sekolah, dan Supervisor Sekolah

5. Manajemen Peserta Didik

Manajemen peserta didik menduduki posisi strategis, karena sentral layanan pendidikan, baik dalam latar institusi persekolahan maupun yang berada di luar latar institusi persekolahan, tertuju kepada peserta didik. Semua kegiatan pendidikan, baik yang berkenaan dengan manajemen akademik, layanan pendukung akademik, sumber daya 
manusia, sumber daya keuangan, sarana prasarana dan hubungan sekolah dengan masyarakat, senantiasa diupayakan agar peserta didik mendapatkan layanan pendidikan yang andal.

Manajemen peserta didik atau pupil personnel administration sebagai suatu layanan yang memusatkan perhatian pada pengaturan, pengawasan dan layanan siswa di kelas dan di luar kelas seperti: pengenalan, pendaftaran, layanan individual seperti pengembangan keseluruhan kemampuan, minat, kebutuhan sampai ia matang di sekolah. Sedangkan pengembangan potensi peserta didik tidak hanya menyangkut ranah kognitif, tetapi juga ranah afektif, dan psikomotor.

6. Manajemen Sarana dan Prasarana

Sarana dan prasarana pendidikan merupakan salah satu sumber daya yang penting dan utama dalam menunjang kegiatan belajar mengajar di sekolah, untuk itu perlu dilakukan peningkatan dalam pendayagunaan dan pengelolaannya, agar tujuan yang diharapkan dapat tercapai. Dewasa ini masih sering ditemukan banyak sarana dan prasarana pendidikan yang dimiliki oleh sekolah yang diterima sebagai bantuan, baik dari pemerintah maupun masyarakat yang tidak optimal penggunaannya dan bahkan tidak dapat lagi digunakan sesuai dengan fungsinya. Hal itu disebabkan antara lain oleh kurangnya kepedulian terhadap sarana dan prasarana yang dimiliki serta tidak adanya pengelolaan yang memadai.

Manajemen perawatan preventif sarana dan prasana sekolah merupakan tindakan yang dilakukan secara periodik dan terencana untuk merawat fasilitas fisik, seperti gedung, mebeler, dan peralatan sekolah lainnya, dengan tujuan untuk meningkatkan kinerja, memperpanjang usia pakai, menurunkan biaya perbaikan dan menetapkan biaya efektif perawatan sarana dan pra sarana sekolah. Dalam manajemen ini perlu dibuat program perawatan preventif di sekolah dengan cara pembentukan tim pelaksana, membuat daftar sarana dan pra saran, menyiapkan jadwal kegiatan perawatan, menyiapkan lembar evaluasi untuk menilai hasil kerja perawatan pada masing-masing bagian dan memberikan penghargaan bagi mereka yang berhasil meningkatkan kinerja peralatan sekolah 
dalam rangka meningkatkan kesadaran merawat sarana dan prasarana sekolah.

Seiring dengan perubahan pola pemerintahan setelah diberlakukannya otonomi daerah, maka pola pendekatan manajemen sekolah saat ini berbeda pula dengan sebelumnya, yakni lebih bernuansa otonomi. Untuk mengoptimalkan penyediaan, pendayagunaan, perawatan dan pengendalian sarana dan prasarana pendidikan pada setiap jenis dan jenjang pendidikan, diperlukan penyesuaian manajemen sarana dan prasarana. Sekolah dituntut memiliki kemandirian untuk mengatur dan mengurus kepentingan sekolah menurut kebutuhan dan kemampuan sendiri serta berdasarkan pada aspirasi dan partisipasi warga sekolah dengan tetap mengacu pada peraturan dan perundangan-undangan pendidikan nasional yang berlaku. Hal itu terutama ditujukan untuk meningkatkan mutu pendidikan pada semua jenis dan jenjang pendidikan, khususnya pada pendidikan dasar dan menengah.

7. Manajemen Keuangan

Manajemen keuangan merupakan salah satu gugusan substansi administrasi pendidikan yang secara khusus menangani tugas-tugas yang berkaitan dengan pengelolaan keuangan yang dimiliki dan digunakan di sekolah dasar. Menurut para pakar administrasi pendidikan, manajemen keuangan pendidikan dapat diartikan sebagai keseluruhan proses pemerolehan dan pendayagunaan uang secara tertib, efektif, efisien, dan dapat dipertanggungjawabkan dalam rangka memperlancar pencapaian tujuan pendidikan. Manajemen keuangan di sekolah terutama berkenaan dengan kiat sekolah dalam menggali dana, kiat sekolah dalam mengelola dana, pengelolaan keuangan dikaitkan dengan program tahunan sekolah, cara mengadministrasikan dana sekolah, dan cara melakukan pengawasan, pengendalian serta pemeriksaan.

Inti dari manajemen keuangan adalah pencapaian efisiensi dan efektivitas. Oleh karena itu, disamping mengupayakan ketersediaan dana yang memadai untuk kebutuhan pembangunan maupun kegiatan rutin operasional di sekolah, juga perlu diperhatikan faktor akuntabilitas dan transparansi setiap penggunaan keuangan baik yang bersumber pemerintah, masyarakat dan sumber-sumber lainnya. 
8. Manajemen Hubungan Sekolah dan Masyarakat

Pendidikan adalah tanggung jawab bersama antara pemerintah (sekolah), keluarga dan masyarakat. Ini mengisyaratkan bahwa orang tua murid dan masyarakat mempumyai tanggung jawab untuk berpartisipasi, turut memikirkan dan memberikan bantuan dalam penyelenggaraan pendidikan di sekolah. Partisipasi yang tinggi dari orang tua murid dalam pendidikan di sekolah merupakan salah satu ciri dari pengelolaan sekolah yang baik, artinya sejauh mana masyarakat dapat diberdayakan dalam proses pendidikan di sekolah adalah indikator terhadap manajemen sekolah yang bersangkutan.

Pemberdayaan masyarakat dalam pendidikan ini merupakan sesuatu yang esensial bagi penyelenggaraan sekolah yang baik. Partisipasi yang tinggi tersebut nampaknya belum terjadi di negara berkembang (termasuk Indonesia). di negara berkembang sebagian besar keluarga belum dapat diharapkan untuk lebih banyak membantu dan mengarahkan belajar murid, sehingga murid di negara berkembang sedikit waktu yang digunakan dalam belajar. Hal ini disebabkan banyak masyarakat atau orang tua murid belum paham makna mendasar dari peran mereka terhadap pendidikan anak. Bahkan di daerah pedesaan yang tingkat status sosial ekonomi yang rendah, mereka hampir tidak menghiraukan lembaga pendidikan dan mereka menyerahkan sepenuhnya tanggung jawab pendidikan anaknya kepada sekolah. Sedangkan kegiatan-kegiatan manajemen hubungan sekolah dan masyarakat adalah sebagai berikut :Analisis kebutuhan keterlibatan masyarakat dalam penyelenggaraan sekolah, Penyusunan program hubungan sekolah dengan masyarakat, Pembagian tugas melaksanakan program hubungan sekolah dengan masyarakat, Menciptakan hubungan sekolah dengan orang tua siswa, Mendorong orang tua menyediakan lingkungan belajar yang efektif, Mengadakan komunikasi dengan tokoh masyarakat, Mengadakan kerjasama dengan instansi pemerintah dan swasta, Mengadakan kerjasama dengan organisasi sosial keagamaan, Pemantauan hubungan sekolah dengan masyarakat dan Penilaian kinerja hubungan sekolah dengan masyarakat. 


\section{Penutup}

Manajemen pendidikan berbasis sekolah adalah kemampuan atau ketrampilan dan sikap seorang pemimpin atau guru untuk memperoleh hasil dalam rangka pencapaian tujuan tertentu melalui cara menggerakkan orang lain yang merupakan suatu proses dimana sumber-sumber yang semula tidak berhubungan satu dengan yang lainnya lalu diintegerasikan menjadi suatu sistem menyeluruh untuk mencapai tujuan-tujuan organisasi. Memimpin terkait dengan menggerakkan dan mengarahkan kegiatan orang, sedangkan "memanage" terkait dengan kegiatan mengatur orang. Mengatur bisa dimaknai secara luas, misalnya menempatkan, memberi tugas, membagibagi, mencarikan jalan keluar, memperlancar dan mengubahubah tugas yang diberikan. Mengelola pendidikan bukanlah hal hal yang mudah untuk dilakukan karena mengelola pendidikan sangat rumit.

Konsep manajemen pendidikan berbasis karakter di sekolah merupakan proses di mana kepala sekolah dasar selaku administrator dan evolutor bersama atau melalui orang lain berupaya mencapai tujuan institusional sekolah dasar secara efisien. Apabila definisi tersebut dikaji secara saksama, terdapat makna tersirat berkenaan dengan konsep manajemen sekolah dasar, yaitu Penyelenggaraan pendidikan bertujuan untuk menghasilkan lulusan yang beriman dan bertakwa pada Tuhan Yang Maha Esa, berakhlak mulia, mengembangkan potensi peserta didik agar jadi anggota masyarakat yang bertanggung jawab dan berkualitas.

\section{Daftar Pustaka}

Abdul Munir. (2006). Seni Mengelola Lembaga Pendidikan Islam. Jakarta: Intelektiva Pustaka.

Anita Yus, Pengembangan Karakter Melalui Hubungan AnakKakek-Nenek, dalam Arismantoro (Peny.), Tinjauan Berbagai Aspek Charakter Building (Tiara Wacana:

Yogyakarta, 2008), h. 91 
Ali Asraf, Horison Baru Pendidikan Islam, (Jakarta: Pustaka Firdaus, 1993), h. 2

Ahmad Maulanah dkk, Kamus Ilmiah Populer, (Cet. II.Yogyakarta: Absolut, 2004), h. 202. 7

Alwisol, Psikologi Kepribadian (Malang: UMM, 2006), h. 8

Doni Koesuma A, Pendidikan Karakter; Strategi Mendidik Anak di Zaman Global, (Jakarta: Grafindo:2010), h. 80

Hasbullah. (2009). Dasar-dasar Ilmu Pendidikan. Jakarta: Rajawali Press.

Kadarman. (1991). Pengantar Ilmu Manajemen. Jakarta: Gramedia.

Malik Fadjar, Holistik Pemikiran Pendidikan, (Jakarta: PT. Raja Grafindo Persada, 2005), h. 68.Purwanto, M. N. (2008). Administrasi dan Supervisi Pendidikan. Bandung: Remaja Rosdakarya.

Masnur Muhlis, Pendidikan Karakter Menjawab Tantangan Krisis Multidimensional, (Jakarta: Bumi Aksara, 2011), h. 70. 24

Sri Nirwanti, Pendidikan Karakter Pengintergrasian 18 Nilai Pembentuk Karakter dalam Mata Pelajaran, (Yogyakarta: Familia, 2011), h. 1. 23.

http://www.Seputarpengetahuan.com/2016/03/6-pendidikankarakter-menurut-para-ahli. html. 25

Tim Penyusun Kamus Pusat Bahasa "Kamus Bahasa Indonesia", h. 700

Wahjosumidjo. (2008). Kepemimpinan Kepala Sekolah Tinjauan Teoritik dan Permasalahannya. Jakarta: Rajawali Press.

Yukl, G. A. (1981). Leadership In Organizations. Englewood: Prentice-Hall Inc. 